\title{
Chromosome Studies of Brazilian Ferns
}

\author{
Alice F. Tryon (1) \\ Hortensia P. Bautista ( ${ }^{2}$ ) \\ Izonete da Silva Araújo ( ${ }^{3}$ )
}

\begin{abstract}
Chromosome numbers, habitat and general geographic distributions are reported for a sample of ferns from the vicinity of Manaus. These numbers are compared with those reported for species in other regions. The report of $\mathrm{n}=$ ca. 154 for Schizaea incurvata is the first record of the genus in the American tropics and the others are first counts of these species in continental South America. In Lindsaea $\mathrm{n}=42$ and $\mathrm{n}=\mathrm{ca}$. 84 , are somewhat lower and appear to represent a line distinct from the species of the paleotropics with $\mathrm{n}=47$. In Trichomanes $n=32,64$ and 128 appear to be levels of polyploidy based on $\mathrm{X}=8$, while $\mathrm{n}=72$ is possibly based on $\mathrm{X}=9$ and suggest possible diverse lines in the genus. Pityrogramma calomelanos with $n=116$ is considered as an octoploid based on $X=29$. Our sample covering about ten percent of the pteridophytes in the area we collected, yielded numbers ranging between $\mathrm{n}=32$ and $\mathrm{n}=154$, and generally appears to represent high polyploid levels.
\end{abstract}

The American tropics has one of the world's richest fern floras encompassing some 4000 species, but cytologically it is poorly known. Cytological surveys of pteridophytes were initiated with studies centering on the British species by Manton (1950) and were soon extended to many regions as India, CeyIon, Japan, West Africa, New Zealand and eastern North America. The most comprehensive study of American species is the survey of Jamaican ferns by Walker (1966) which encompasses 270 of some 540 species listed for the island. This is a major contribution to the subject and the most useful reference for our work. There are essentially no cytological investigations of the ferns of continental South America. This point is clearly made in a re- cent paper by Britton (1974) which summarizes the work in fern cytology and indicates they are rather well sampled except for those of South America and mainland China. The opportunity to include a section on cytology in the Class of Pteridophyta, taught during September and October 1974, as part of the Curso de Botânica Tropical do Instituto Nacional de Pesquisas da Amazônia was taken to begin work with Brazilian students. We hope that this sample of our accomplishments over a relatively brief period will motivate further studies in the Amazonian area and in other parts of South America.

\section{MATERIALS AND METHODS}

Leaves with young sporangia were fixed in Farmer's solution consisting of 1 part glacial acetic acid to 3 parts absolute alcohol. Some material fixed in $96 \%$ alcohol softened, for example, see Fig. 10 of Trichomanes pilosum, and the chromosomes are not wellspread. The slides were prepared by removing sporangia from the leaves into a drop of fixative. A drop of aceto-carmine was added after the solution evaporated; the slide was then heated over an alcohol lamp, and squashed. Preparations were made permanent by inverting the slides on glass rods in $95 \%$ alcohol, until the cover glass dropped, and mounting in Diaphane.

Meiotic figures obtained in eleven species are illustrated and discussed in this paper. Collections were made at four localities in the vicinity of Manaus - at the Instituto Nacional

(1) - Gray Herbarium, Harvard University, Cambridge, Massachusetts 02138.

(2) - INPA, Museu Paraense Emílio Goeldi, Belém. Bolsista do CNPq.

(3) - Instituto Nacional de Pesquisas da Amazônia, Manaus. Bolsista do CNPq. 
de Pesquisas da Amazônia (INPA), at the Reserve Florestal Ducke ( $\mathrm{km} \mathrm{26)}$, on the Manaus to Itacoatiara road, at the Estação Experimental de Silvicultura Tropical ( $\mathrm{km} \mathrm{60)}$ ), and at $\mathrm{km}$
130 on the Manaus to Caracaraí road. Permanent slides and herbarium vouchers are deposited at the Gray Herbarium, Harvard University.

\section{Schizaea}

\section{Species, voucher}

S. incurvata Schkur INPA, Conant 1103

Manaus.

This is one of the two species of Schizaea frequent on the open, white sandy campina areas that are interspersed among the forests, near Manaus. This and S. pennula Sw. form large colonies in open sunny places or often among shrubs at the edge of the forest. The sterile leaves of both species are filiform, characteristic of a group of species in Schizaea, but the fertile ones are quite distinct. The fertile segments of $S$. incurvata are attached laterally to a central rachis and are often conduplicate as in Fig. 1. Those of $S$. pennula are clustered at the petiole apex in a tufted arrangement.

This report of ca. 154 in Schizaea incurvata (Fig. 2), the first cytological record of the genus for the American tropics, is relatively high for the pteridophytes. There are some problems in working with such high numbers of chromosomes but there are also compensations in these plants. They have large sporangia with many more megasporocytes than in

\section{General Distribution}

Guianas, Amazonian, Brazil, Upper Orinoco and Gran Sabana, Venezuela, Vaupés, Colombia.

species of the Polypodiaceae in which there usually are only 16 spore mother cells per sporangium. In this material of Schizaea the chromosomes were easily spread, and meiosis appears to be synchronized with numerous nuclei in different phases of diakinesis within a single sporangium.

The chromosome number in Schizaea in. curvata is clearly polyploid although the level is difficult to establish. The lowest number reported for the genus is $n=77$ in $S$. asperula Wakefield, from New Zealand. The same number is reported in S. dichotoma (L.) Smith, from Ceylon while another specimen of the species, from New Zealand is reported as $n=540$. This large number of chromosomes approaches that in Ophioglossum reticulatum L., from India which is illustrated by Ninan (1958) with $n=630$, the largest number of chromosomes reported for any living organism. It is interesting to note that the leaf form in Schizaea is a simple one as it is in Ophioglossum.

\section{Trichomanes}

\section{Species, voucher}

T. arbuscula Desv.

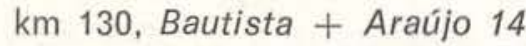

T. cristatum Kaulf. $\mathrm{km}$ 60, Bautista + Araújo 22

T. elegans Rich. Ducke, Bautista + Araújo 4

T. pilosum Baddi km 130, Bautista + Araújo 20

T. tanaicum Hook. Ducke, Bautista + Araújo 3

\section{Meiotic number}

ca. 128

ca. $62-68$ 

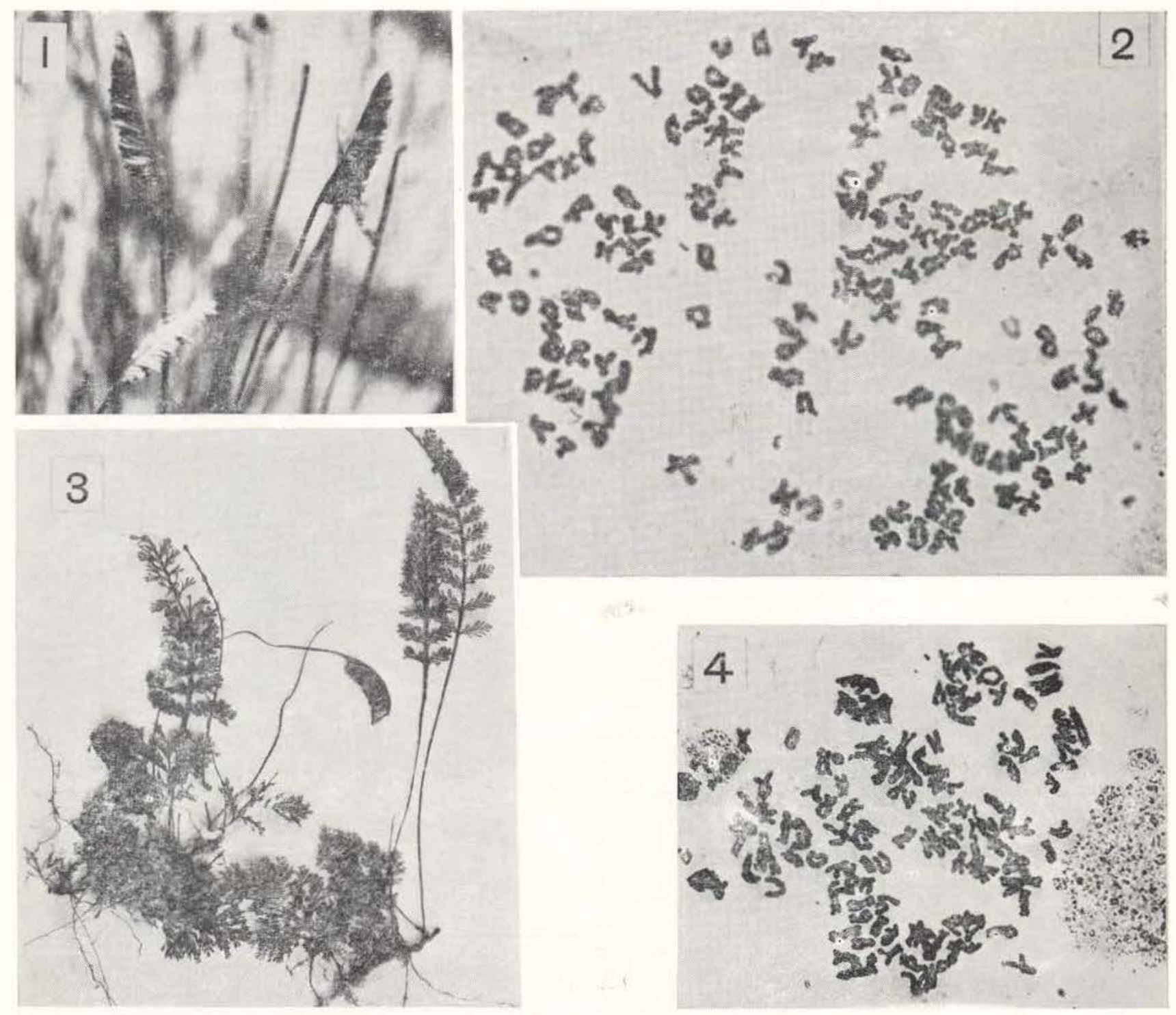

Fig. 1 - Leaves of Schizaea incurvata Schkuhr, two of the three fertile ones with conduplicate segments, growing at the Campina, $\mathrm{km} 60$. Fig. 2 - Meiotic chromosomes of Schizaea incurvata $\mathrm{n}=\mathrm{ca}$. 154 showing various types of bivalent associations, $\mathrm{X} 800$. Fig. 3 - Dimorphic leaves in voucher collection of Trichomanes arbuscula Desv., the fertile ones long petiolate. Fig. 4 - Late diplotene chromosomes of T. arbuscula $\mathrm{n}=\mathrm{ca} .128$ showing various types of bivalent associations, $\mathrm{X} 600$.

Some of the extreme morphological and ecological diversity among the species of Trichomanes is shown in the sample of species cytologically studied. All of them grow in generally moist, shaded situations but occupy quite different habitats. Trichomanes arbuscula forms dense colonies near the edge of the water, along stream banks. The leaves are dimorphic with the fertile ones long petio. late (Fig. 3). Leaves of $T$. cristatum are monomorphic, caespitose and with a deeply pec- tinate lamina. Only a few plants were found in dense moss at the base of a large tree. Trichomanes elegans has exceptionally large leaves for the genus with the lamina finely dissected and more than $30 \mathrm{~cm}$ long (Fig. 5). We found only a single plant along a stream bank with the leaves overhanging the water. Plants of $T$. pilosum were abundant on the face of shaded sandstone rocks. The caespitose leaves (Fig. 9) are covered with dense indument. Trichomanes tanaicum is scandent and 
quite a rare species although with a rather wide distribution in northern South America. We found only a single plant (Fig. 7) on an upright, dead tree trunk.

The species of Trichomanes are excellent cytological subjects for many have relativeiy few, and remarkably large chromosomes as in Fig. 6 of T. elegans and Fig. 8 of T. tanaicum. The bivalents in $T$. arbuscula (Fig. 4) are so. mewhat smaller but are in an earlier, diplotene stage prior to diakinesis. This species has ca. 128 bivalents, the highest number known for the genus which has also been reported in $T$. crispum L. from Jamaica, by Walker (1966). He also has a record of $n=64$ in $T$. arbuscula from Trinidad, which is considered as possibly $16 \mathrm{X}$. Thus our collection from Brazil with $n=128$ may be $32 X$. The chromosome
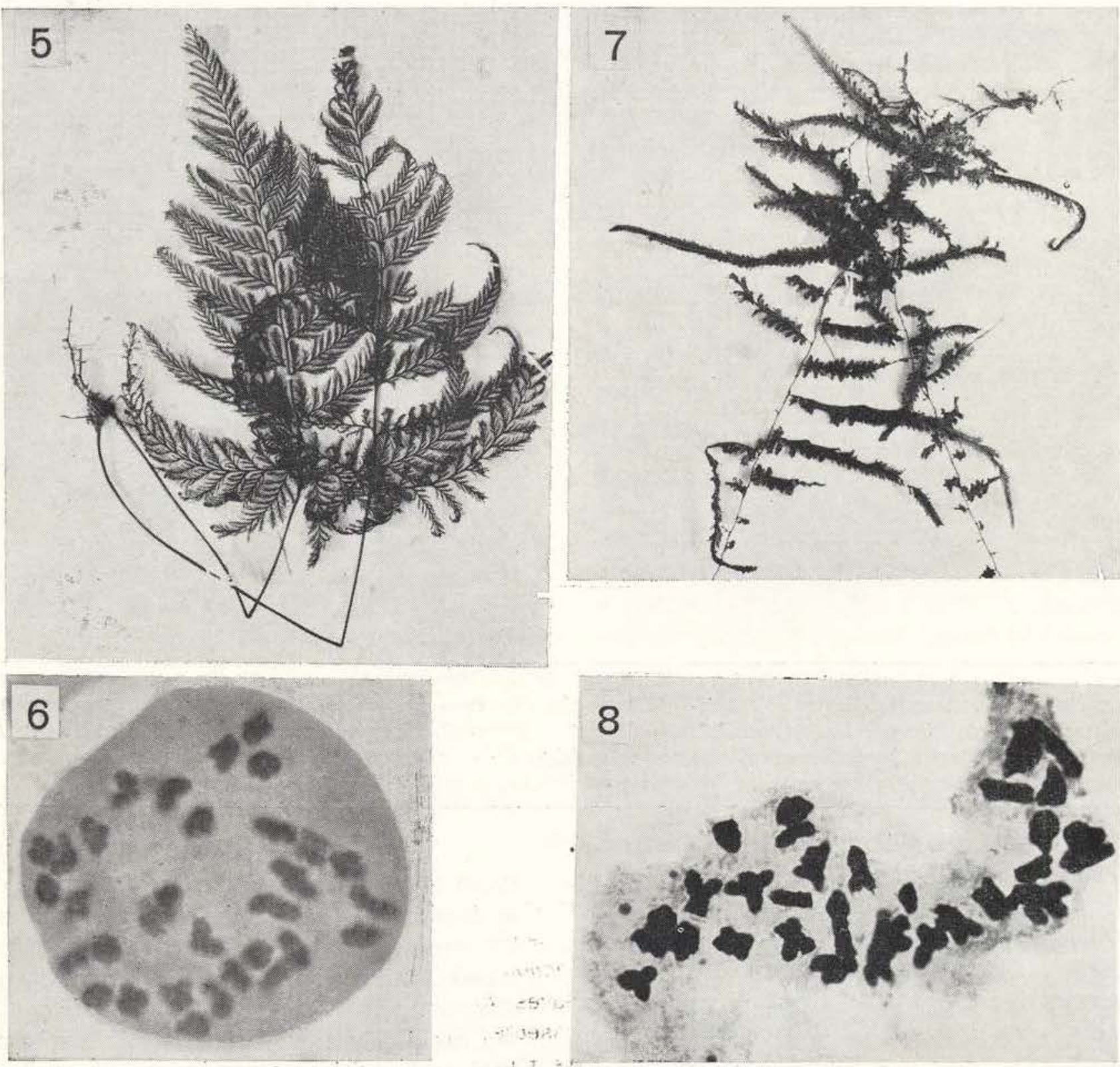

Fig. 5-Voucher collection of Trichomanes elegans Rich. with highly divided monomorphic leaves. Fig. 6 - Chromosomes of Trichomanes elegans at diakinesis $\mathrm{n}=32, \mathrm{x} 1000$. Fig. 7 - Voucher collection of Trichomanes tanaicum Hook. with scandent rhizomes. The numerous elongate leaves with slender, marginal sori. Fig. 8 - Chromosomes of $\mathbf{T}$. tanaicum at diakinesis $\mathrm{n}=32, \mathrm{X} 1000$. 
number of $T$. pilosum between $n=62-68$ (Fig. 10 ) is not clear because of several superimposed bivalents, but certainly represents a relatively high polypioid level.

The species of Trichomanes are also good cytological subjects because of the gradate sorus. Meiosis can usually be found on the receptacle between the basal point where sporangia are initiated and the apex where they are dehiscing. Our record of $n=32$ in both $T$. elegans and $T$. tanaicum, which are morphologically very distinct, indicates that number may be established in different evolutionary lines. Consideration of the chromosome numbers along with other aspects of the plants suggests that $\mathrm{n}=72$ in $T$. cristatum (Fig. 11) may be constituted from a line based on 9 rather than 8 as in the other species.

Trichomanes elegans is a very distinctive species and has been treated in subgenus

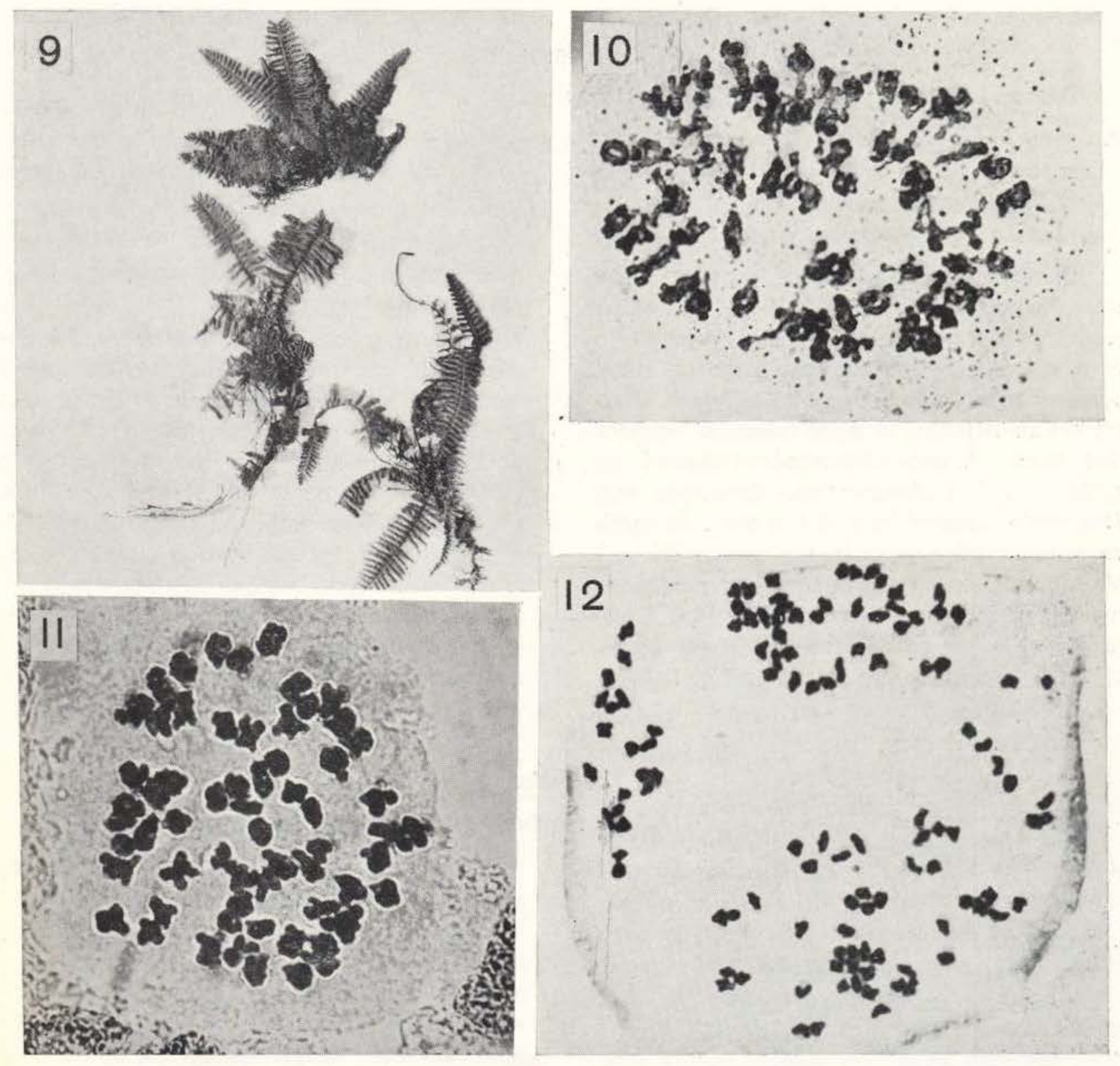

Fig. 9 - Specimens of Trichomanes pilosum Raddi with caespitose leaves. Fig. 10 - Meiotic chromosomes of Trichomanes pilosum with several superimposed bivalents $\mathrm{n}=\mathrm{ca}, 62-68, \mathrm{X} 1000$. Fig. $11-\mathrm{Chromo}$ somes of Trichomanes cristatum Kaulf. at diakinesis $\mathrm{n}=72, \mathrm{x} 1000$. Fig. 12 - Chromosomes of Pityrogramma calomelanos (L.) Link var. calomelanos at diakinesis $n=116, X 800$, 
Pachychaetum, in its own section Davalliopsis, in the treatment of the genera of the Hymenophyllaceae by Morton (1968). In that work, T. tanaicum and the other species that have been studied here are placed in different sections of the subgenus Achomanes.

Chromosome numbers have been reported in about 77 species of the Hymenophyllaceae and there is a considerable range of numbers between 11 and 128. Derivation of the numbers in the Hymenophyllaceae has been dis- cussed in considerable detail by Walker (1966) and he postulates $6,7,8$, and 9 as base numbers. In this system our records of 32,64 and 128 would be based on 8 , while 72 would be on 9. The scheme of Walker seems more plausible than one proposed by Vessey \& Barlow (1963) in which chromosomes are lost and different sets are combined to arrive at the correct sum. In that scheme $n=32$ would be based on $X=17$ with the loss of one and doubling to 32 .

\section{Pityrogramma}

\section{Species, voucher}

P. calomelanos (L.) Link var. calomelanos

km 130, Bautista + Araújo 11
Meiotic number

116

\section{General Distribution}

Wide ranging from Mexico south to Bolivia and Argentina, Antilles and Floride
Plants are often abundant in open, sunny sites especially in disturbed places along roadsides and on cleared hillsides. There were large colonies at $\mathrm{km} 130$ where we collected our specimen at the edge of the forest. Pityrogramma belongs to a complex of genera that have chromosome numbers based on $X=29$, including Anogramma, Eriosorus, and Jamesonia, although one of the most distinctive species, Pityrogramma triangularis (Kaulf.) Maxon, in California has a diploid race with $n=30$ and a tetrapolid race with $n=60$. Several nuclei in our preparations of Pityrogramma calomelanos are clearly $n=116$ as Fig. 12. The species is reported as $n=c a$. 120 , from Jamaica, by Walker (1966). That same number is given for a specimen from northern India, and there are also records of $n=116$ for plants from southern India and Formosa. The species is regarded as wholly American, in the taxonomic treatment of the genus by R. Tryon (1962), but it is noted that it has been introduced in many areas of the paleotropics. It is a frequent species in the American tropics. Further cytological work to determine whether both numbers do indeed occur in different populations and especially whether lower diploid populations occur in the American trop.cs, will be of much interest.

\section{Lindsaea}

\section{Species, voucher}

L. divaricata $\mathrm{KI}$. Ducke, Bautista + Araújo 2

L. lancea (L.) Bedd. var. falcata (Dryand.) Rosens. $\mathrm{km} \mathrm{60,} \mathrm{Bautista} \mathrm{+} \mathrm{Araújo} 24$

L. quadrangularis Raddi ssp. subalata Kraemer km 130, Bautista + Araújo 18

L. schomburgkii $\mathrm{KI}$. km 130, Bautista + Araújo 16
Meiotic number univalents

ca. 84

\section{General Distribution}

Guatemala south to Bolivia and Paraguay and also in Guadeloupe

Panama south to Bolivia, Pará, and in Bahia 
Lindsaea is a frequent genus in the moist forests around Manaus and two or three species may occupy the same site. The plants are terrestrial, commonly on stream banks and in open places in the forest. Lindsaea lancea var. falcata occurs in all of the localities we collected and there are many scattered plants in open places in the forest. The leaves have compact pinnae with a large terminal segment (Fig. 13). Lindsaea schomburgkii is a rarer species growing in open, more exposed places with longer leaves and somewhat coriaceous pinnae. Lindsaea divaricata and $L$. quadrangularis have similar more complex leaves with smaller segments. L. divaricata (Fig. 15) occurs in somewhat wetter sites.

There are few cytological records for American species. The chromosomes are difficult to study because of their relatively small size and the tendency for bivalents to adhere. Sporangia at meiosis are quite small as compared to other genera. A report of Lindsaea arcuata Kze. with $n=84$ was made by Mickel et al. (1965) based on a collection from Oaxaca, Mexico. Lindsaea portoricensis Desv. was reported from Jamaica as $n=c a$. 88 , by Walker (1966) and was considered to be tetraploid. On the basis of this earlier work on the genus, it appears that our material of $L$. lancea var. falcata (Fig. 14) and L. divaricata (Fig. 16) represent diploids and L. schomburgkii (Fig. 18) is tetraploid. The cell shown here of $L$. quadrangularis (Fig. 17) with $84-88$, largely univalents and some multivalents, at arrow, is one of three cells examined with mostly unpaired chromosomes. The univalent and multivalent associations in this material indicate an abnormal meiosis.

In the treatment of American Lindsaea by Kramer (1957), L. lancea var. falcata and L. schomburgkii are placed in subsection Terminales and $L$. arcuata, $L$. divaricata and $L$. quadrangularis in subsection Decrescentes. There appears to be no cytological differentiation between these subsections since species with $n=42$ occur in each of them.

There are many cytological records for paleotropical species of Lindsaea and meiotic chromosome numbers range between 34 and 155. The most frequent, $n=47$, is reported in nine species from widely distant areas as $L$. vieillardii Mett. from New Caledonia, $L$. chienii Ching, from Japan, L. concinna J. Sm., from Australia, and in L. parallelogramma $\vee A$. $\checkmark$ R. from Malaya. However, there are other numbers also reported for species of the paleotropics as $n=34$ in L. linearis Sw. from New Zealand and $n=82$ in L. caudata Hook. from Ceylon which show that changes in chromosome numbers have occurred other than polyploid doubling of the complement. The record of $n=42$ in L. trichomanoides Dryand., by Brownlie (1956) suggests a possible common base number among species of both regions. However, the gross morphology of L. trichomanoides, especially the leaves is so different from the specimens that we have studied that it appears a connection between them is probably a distant one.

\section{DISCUSSION}

The relatively small sample of chromosome numbers reported for the Amazonian region does not allow broad comparisons with other geographic areas as has been done for England where the whole fern flora has been examined. The number of pteridophyta in Amazonia is estimated at about 300 species and about 100 occur in the area we collected around Manaus; our cytological sample represents about ten percent of these. Some preliminary comments can be made relative to other records especially for Lindsaea and Trichomanes. The report of $L$. portoricensis with $\mathrm{n}=$ ca. 88 , from Jamaica was considered a tetraploid, thus our record of $n=42$ is probably diploid and $n=$ ca. 84 tetraploid. Several Lindsaea species with $\mathrm{n}=47$ in the paleotropics suggest that there are distinct evolutionary lines in these two regions.

Cytologically Trichomanes is one of the best known genera and there are reports of the following meiotic numbers: $21,22,26,32$, $33,34,35,36,56,64,68,72,108,128$. Most are at higher levels than our reports. If 8 is considered a base number for the group, $n=32$ 


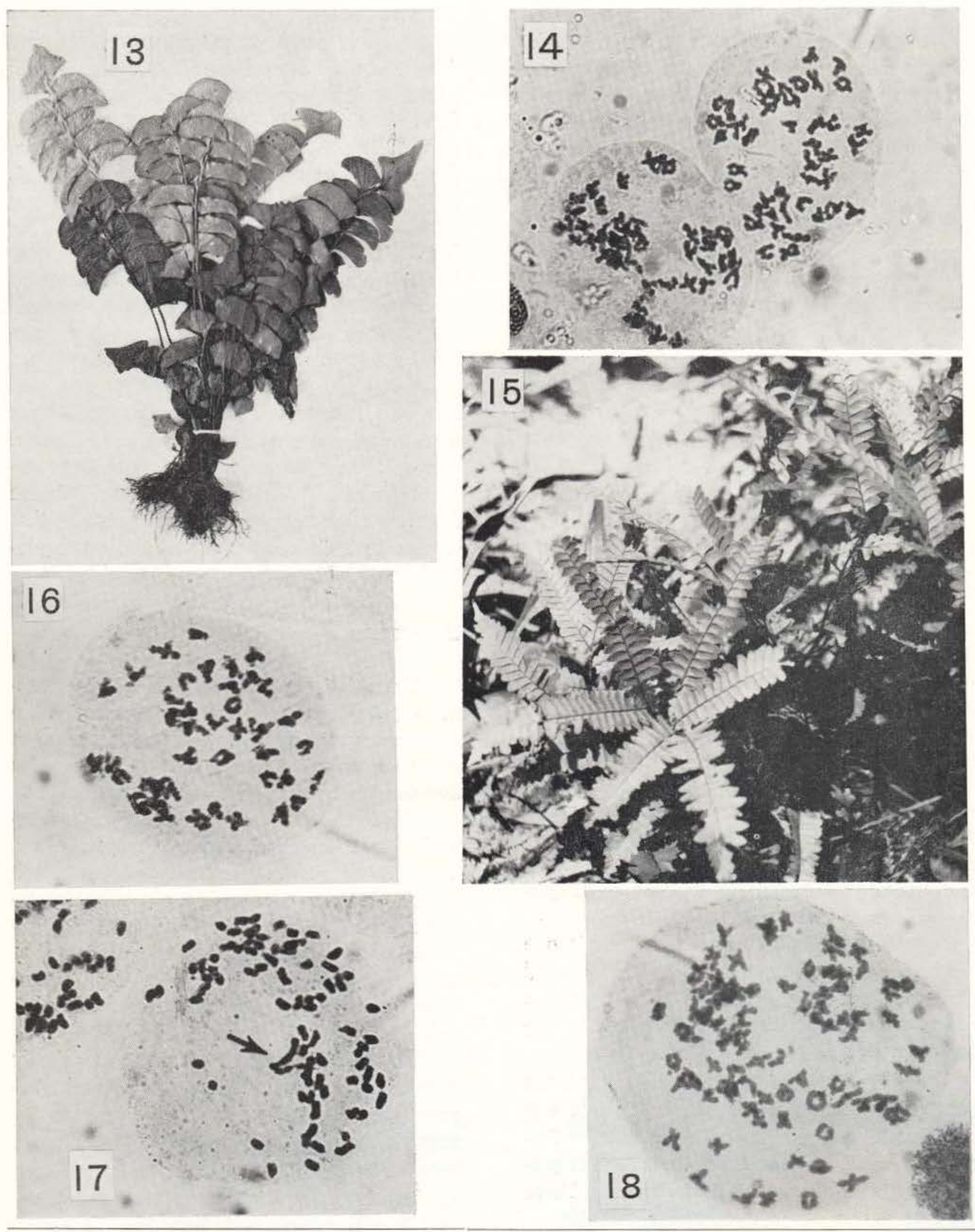

Fig. 13 - Voucher collection of Lindsaea lancea (L.) Bedd. var. falcata (Dryand.) Rosenst. Fig. 14 - Meio. tic nuclei of Lindsaea lancea var. falcata $n=42, X 1000$. Fig. 15 - Habit of leaves of Lindsaea divaricata $\mathrm{Kl}$. growing at Reserva Florestal Ducke. Fig. 16 - Nucleus of Lindsaea divaricata at early diakinesis $\mathrm{n}=42$, $\mathrm{X}$ 1000. Fig. 17 - Meiotic nuclei of Lindsaea quadrangularis Raddii ssp. subalata Kramer with 84-88 lar. gely univalents and some bivalents, at arrow, X 1000. Fig. 18- - Meiotic chromosomes of Lindsaea schomburgkii Kl. $\mathrm{n}=$ ca. $84, \mathrm{X} 1000$ 
would represent an octoploid and our highest number $\mathrm{n}=128$ would be $32 \mathrm{X}$. Pityrogramma calomelanos with $\mathrm{n}=116$ represents an octoploid based on $X=29$. The highest number among the species we report, $\mathrm{n}=\mathrm{ca}$. 154 , in Schizaea incurvata, is intermediate in the series of numbers reported for species of the paleotropics and one of North America with
$77,94,96,103,270,325( \pm 30), 350-370$, and 540. A base number for Schizaea was proposed as $X=77$. If this is accepted, our specimens would represent a relatively low level of ploidy, in spite of the high number of bivalents.

The following table summarizes our reports on Amazonian fern cytology.
Species Locality

\section{Number Maiotic}

Figure Number
Schizaea incurvata Schkuhr

Trichomanes arbuscula Desv.

T. cristatum Kaulf.

T. elegans Rich.

T. pilosum Raddi

T. tanaicum Hook.

Pityrogramma calomelanos (L.) Link var. calomelanos

Lindsaea divaricata $\mathrm{Kl}$.

L. lancea (L.) Bedd. var.

falcata (Dryand.) Rosenst.

L. quadrangularis Raddi ssp.

subalata Kramer

L. schomburgkii Kl.

INPA Station
$\mathrm{km} 130$
$\mathrm{~km} 60$
Ducke
km 130
Ducke

km 130

Ducke

$\mathrm{km} 60$

$\mathrm{km} 130$

$\mathrm{km} 130$

$\begin{array}{lr}\text { ca. } 154 & 2 \\ \text { ca. } 128 & 4 \\ 72 & 11 \\ 32 & 6 \\ \text { ca. } 62-68 & 10 \\ 32 & 8 \\ & \\ 116 & 12 \\ 42 & 16 \\ & \\ 42 & 14 \\ 84-88 & \\ \text { univalents } & 17 \\ \text { ca. } 84 & 18\end{array}$

\section{ACKNOWLEDGEMENTS}

We are grateful to Dr. Ghillean T. Prance, Director of the Curso de Botânica Tropical do INPA for expediting our field and laboratory work. Dr. Osório Fonseca generously helped with some photographs of the chromosomes, and David Conant and Rolla Tryon assisted in herbarium and field work.

\section{RESUMO}

São apresentados números de cromossomos, habitats e distribuição geral de 11 espécies (4 gêneros) de pteridófitas da regiăo de Manaus. Estas são as primeiras contagens cromossômicas destas espécies na América do Sul. São feitas comparações com números referidos para estes gêneros em outras regiōes geográficas. Os números variam entre $n=32$ e $n=154$ e parecem representar altos niveis de poliploidia.

\section{LITERATURE CITED}

BRITTON, D. M.

1974 - The significance of chromosome numbers in ferns. An, Mis. Bot. Gard., 61 (2): $310-317$.
BROWNLIE, G.

1965 - Chromosome numbers in some Pacific pteridophyta. Pacific Sci., 19 (4): 493-497.

KRAMER, K. U,

1957 - A revision of the genus Lindsaea in the new world with notes on allied genera.

MANTON, I. Act. Bot. Neerlandica, 6: $97-290$

1950 - Problems of cytology and evolution in the pteridophyta. Cambridge, England.

MICKEL, J. T.

1966 - Chromosome observations on the ferns

MORTON, C. V. of Mexico. Caryologia, 19 (1): 95-102.

1968 - The genera, subgenera, and sections of the Hymenophyllaceae. Contr. U. S. Nat. Herb., 38 (5): 153-214.

NINAN, C. A.

1958 - Studies on the cytology and phylogeny of the pteridophytes 6. Observations on the Ophioglossaceae. 23 (3): 291-316.

TRYON, R. M.

1962 - Taxonomic fern notes 2. Pityogramma (including Trismaria) and Anogramma. Contr. Gray Herb., 189: 52-76.

VESSEY, J. \& BARLOW, B. A.

1963 - Chromosome numbers and phylogeny in the Hymenophyllaceae. Proc. Linn.

WALKER, T. G.

1966 - A cytotaxonomic survey of the pteri dophytes of Jamaica. Trans. Roy. Soc. Edinburgh, 66 (9): 169-237. Soc. N. S. W., 88: 301-306. 